\title{
The Distribution of T and B Lymphocyte Populations and MHC Class II Expression in Human Fetal and Postnatal Intestine
}

\author{
GARY J. RUSSELL, ATUL K. BHAN, AND HARLAND S. WINTER \\ Combined Program in Pediatric Gastroenterology and Nutrition, The Children's Hospital and the Department of \\ Pathology, Massachusetts General Hospital; Harvard Medical School, Boston, Massachusetts 02115
}

\begin{abstract}
The development of the intestinal mucosal immune barrier is an important protective adaptation for postnatal life. The distribution and phenotype of $T$ and $B$ lymphocytes in human fetal intestine and lymphoid tissues have been characterized and compared to the distribution and phenotype of lymphocytes in postnatal intestine. The characterization of lymphocyte phenotype and MHC class II antigen distribution was done using $\mathrm{MAb}$ and an avidinbiotin complex immunohistochemical staining technique. Intraepithelial lymphocytes were occasionally present in fetal intestine and were primarily $\mathrm{CD3}^{+}, \mathrm{CD8}^{+}$. $\mathrm{T}$ lymphocytes were readily identified in the lamina propria of fetal intestine, but most were clustered in lymphoid aggregates. Cells identified by anti-IgA $A_{1}$ and anti-IgA $A_{2}$ were the most numerous cells of $\mathbf{B}$ cell lineage in the lamina propria of postnatal intestine, whereas $\mathrm{IgM}^{+}$and $\mathrm{IgD}^{+}$lymphocytes predominated in fetal tissues. However, IgA-bearing cells were identified in lymphoid aggregates of the intestine or spleen of some fetuses. This finding suggests that B lymphocytes can undergo Ig switching in utero. Additionally, fetal intestinal epithelial cells did not express MHC class II antigens, unlike some postnatal intestinal tissues. It is possible that postnatal events such as antigen exposure may be important for the induction of these class II antigens on intestinal epithelial cells. (Pediatr Res 27:239244,1990 )
\end{abstract}

The postnatal development and maturation of the intestinal mucosal immune barrier is an important host defense mechanism to prevent the penetration and uptake of bacteria, toxins, and potentially damaging antigens (1). Previous reports on the phenotypic characterization and tissue distribution of human fetal lymphocytes have focused primarily on lymphocytes found in thymus, spleen, liver, lymph nodes, and bone marrow (2-6). Limited information is currently available on the development of the human gut-associated lymphoid tissue. Immunohistochemical examination of human fetal terminal ileum has demonstrated that by 19-22 wk gestation, the gut epithelium and lamina propria contain many isolated $\mathrm{T}$ cells and the lamina propria contains aggregates of $T$ and $B$ cells (7-9). Our study evaluates the distribution of $\mathrm{T}$ and $\mathrm{B}$ lymphoid populations and MHC class II antigen expression in human fetal intestine in comparison with normal postnatal intestine.

Received June 29, 1989; accepted November 2, 1989.

Correspondence Gary J. Russell, M.D., Combined Program in Pediatric Gastroenterology and Nutrition Unit, Hunnewell Ground, The Children's Hospital, 300 Longwood Ave., Boston, MA 02115.

Supported by a grant from The Hood Foundation to G.J.R., NIH Grant AI27747 to H.S.W., and NIH Grant DR-33506 to A.K.B.

\section{MATERIALS AND METHODS}

Tissue samples. Fetal tissues were obtained within $2 \mathrm{~h}$ after prostaglandin/saline-induced abortions. The estimated fertilization age of the fetuses was determined by crown-rump length, foot length, and fetal wt during postmortem examination (10, 11). The following tissues were harvested from six fetuses, 1721 wk estimated fertilization age: proximal jejunum, distal ileum, cecum, colon, spleen, thymus, and liver. Procurement of human tissues and the consent forms were approved by the Committee for the Protection of Human Subjects from Research Risks at the Brigham and Women's Hospital and The Children's Hospital, in accordance with the Declaration of Helsinki.

Histologically normal intestinal tissue from children ranging in age from $1 \mathrm{~d}$ to $3 \mathrm{y}, 10 \mathrm{mo}$ was obtained from surgical specimens submitted to the Pathology Department (Table 1). The tissue samples were embedded in OCT Compound (Ames Co., Elkhart, IN), snap frozen in liquid nitrogen or isopentane $\left(-70^{\circ} \mathrm{C}\right)$ and stored at $-70^{\circ} \mathrm{C}$.

$M A b$. The MAb used in this study include B1 (CD20), B2 (CD21), (Coulter Corp., Hialeah, FL), anti-IgA $A_{1}$, anti-IgA $A_{2}$, antiIgG, anti-IgM, anti-IgD, Leu 2a (CD8), Leu 3a (CD4), Leu 4 (CD3), Leu 6 (CD1), anti-HLA-DR, anti-HLA-DQ, anti-HLADP (Becton Dickenson, Mountain View, CA), anti-HLA-A,B,C (Bioproducts for Science Inc., Indianapolis, IN) and OKT8 (CD8) (Ortho Pharmaceutical Corp., Raritan, NJ). This panel of antibodies was chosen so that aspects of $\mathrm{B}$ cell, $\mathrm{T}$ cell, and antigen presenting cell development could be evaluated.

Immunoperoxidase staining. Frozen tissue sections 4- to 6- $\mu \mathrm{m}$ thick were fixed in acetone and stained by the previously described avidin-biotin complex method (12). Briefly, the tissue sections were incubated with MAb at an optimal dilution for 1 $\mathrm{h}$ followed by incubations with 1:240 dilution of biotinylated horse anti-mouse antibody and a 1:120 dilution of avidin-biotinylated peroxidase complex (Vector Laboratories, Inc., Burlingame, CA). Negative control slides were incubated with PBS, pH 7.3 instead of a primary antibody. A positive control known to express the antigen of interest was also processed in parallel. Each incubation was followed by three washes in PBS. Endogenous peroxidase activity was blocked by a 20 -min incubation in $0.3 \%$ hydrogen peroxide in PBS. Tissue sections of fetal liver

Table 1. Tissue samples of postnatal intestine

\begin{tabular}{ll}
\hline \multicolumn{1}{c}{ Diagnosis } & \multicolumn{1}{c}{ Age } \\
\hline Duodenal atresia (1) & $1 \mathrm{~d}$ \\
Biliary atresia (1) & $4 \mathrm{mo}$ \\
Intestinal stricture (1) & $8 \mathrm{mo}$ \\
Hirschsprung's disease (1) & $14 \mathrm{mo}$ \\
Intussusception (1) & $16 \mathrm{mo}$ \\
Choledochal cyst (2) & 3 y $10 \mathrm{mo}, 6 \mathrm{mo}$ \\
\hline
\end{tabular}



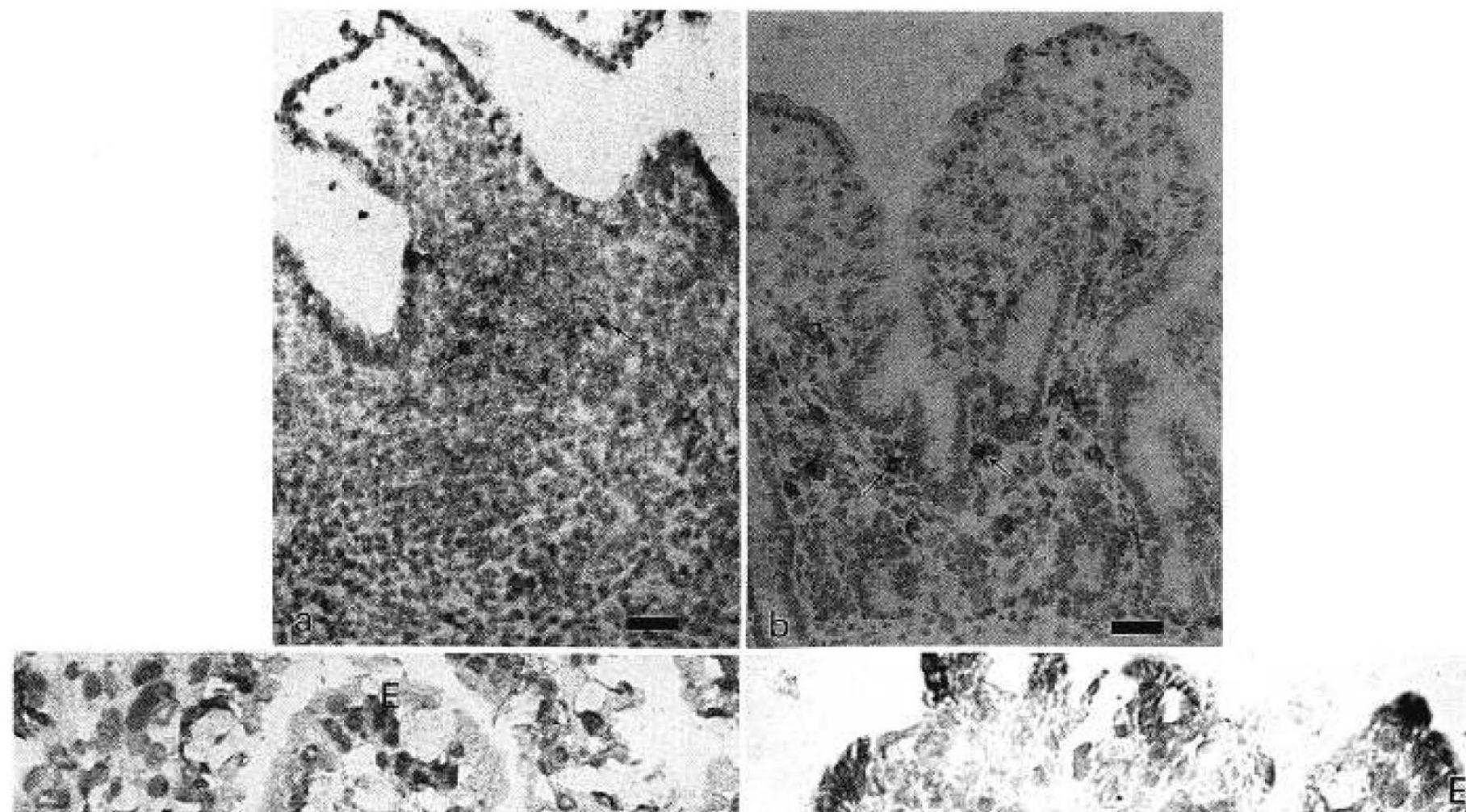

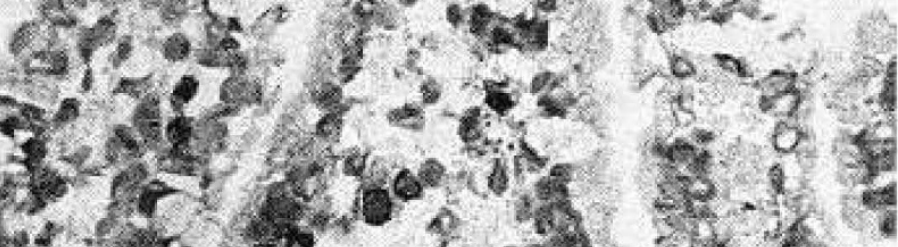

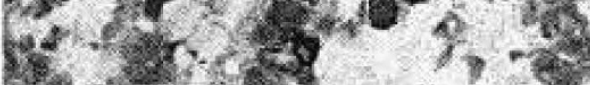

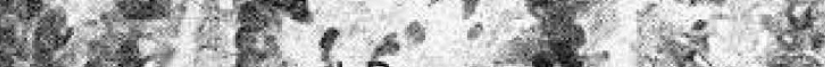

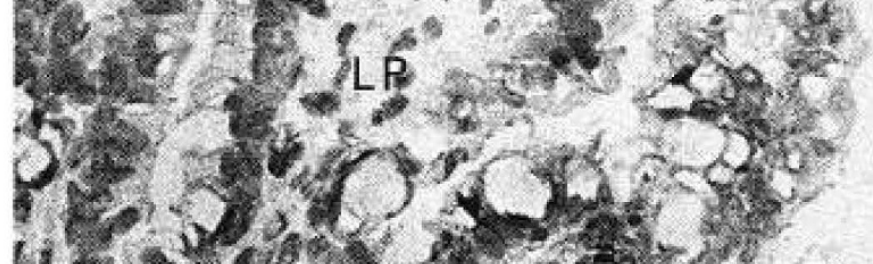

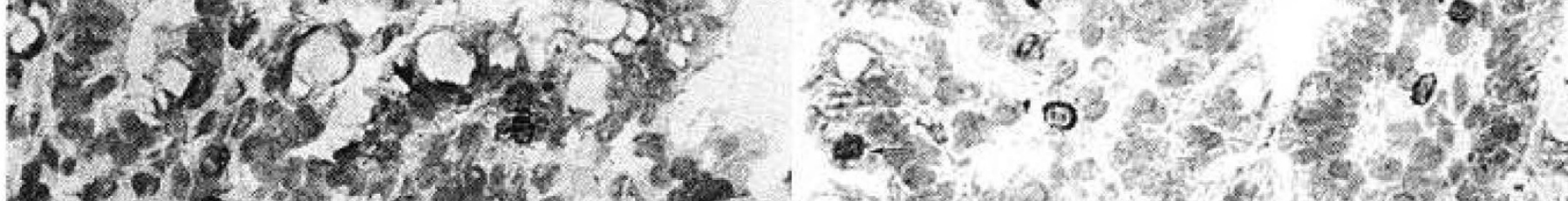

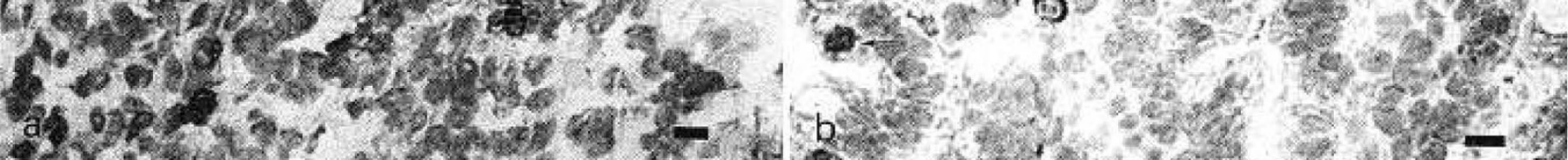

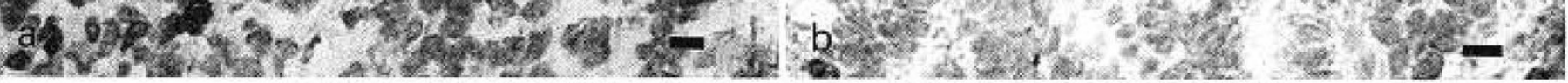
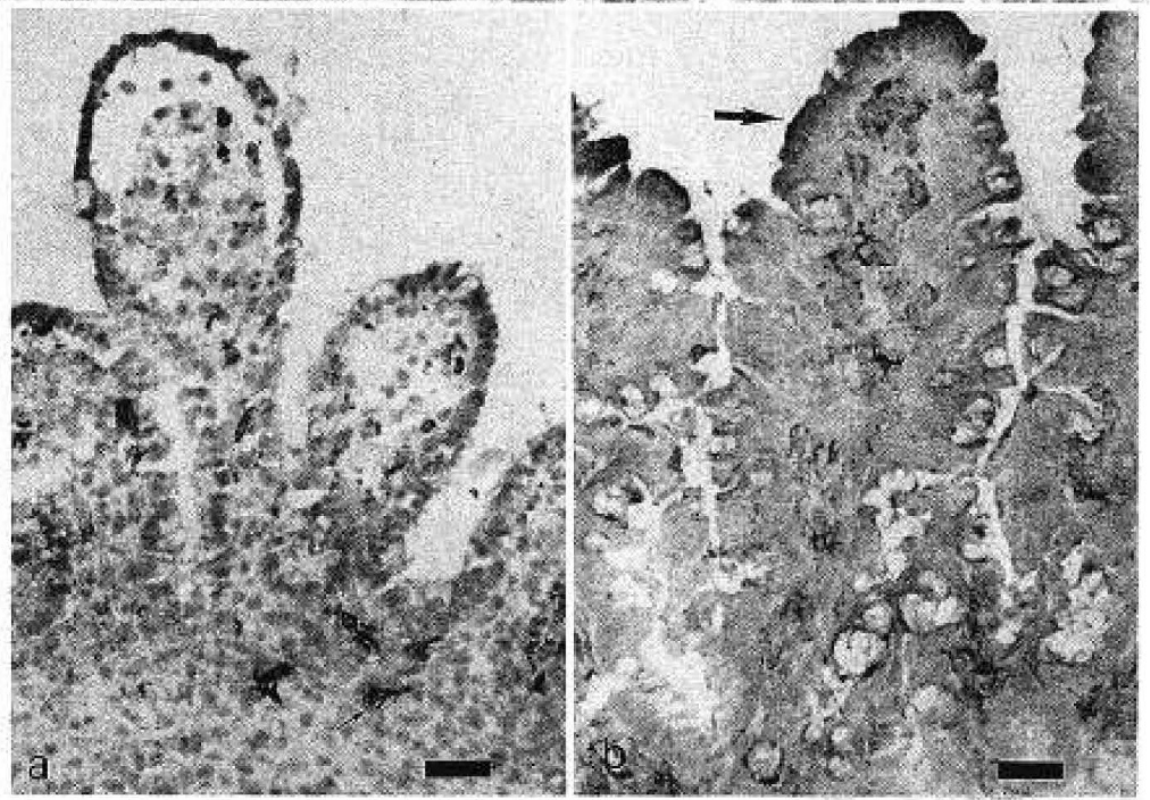
were also incubated with avidin and then biotin (Vector Laboratories) before the incubation with biotinylated horse antimouse antibody to block endogenous biotin. The sections were stained by incubating in a solution of 3-amino-9-ethylcarbazole (Aldrich Chemical Co., Inc., Milwaukee, WI), postfixed in 4\% formaldehyde, counter stained with hematoxylin and mounted in Glycergel (Dako Corp., Santa Barbara, CA).

\section{RESULTS}

Thymus. The staining observed in the fetal thymus with antibodies against $T$ cells was consistent with previous reports on fetal thymocyte suspensions $(2,13)$ and immunohistochemical staining of postnatal thymic tissue (14). Cortical thymocytes demonstrated peripheral staining with antibodies against CD1, CD3, CD4, and CD8. The majority of the medullary thymocytes was $\mathrm{CD}^{+}$but many were $\mathrm{CD}^{+} . \mathrm{IgM}^{+}$and $\mathrm{IgD}^{+}$cells were present in the medulla, but no $\mathrm{IgG}^{+}, \mathrm{IgA}_{1}{ }^{+}$, or $\operatorname{IgA}_{2}{ }^{+}$cells were identified. Many $\mathrm{CD} 20^{+}$, and to a lesser extent $\mathrm{CD} 21^{+}$, cells were found in the medulla. These cells were larger than medium size lymphocytes and demonstrated membrane staining. Prominent diffuse (cytoplasmic) and some membrane staining was present in the medulla with the antibodies against MHC class II antigens. Patchy dendritic staining occurred in the cortex with anti-HLADR and anti-HLA-DQ, but there was minimal cortical staining with anti-HLA-DP. This staining pattern was most consistent with the staining of epithelial cells; however, staining of some thymocytes cannot be excluded.

These results are consistent with the protein that immature thymocytes reside in the cortex and mature thymocytes are present in the medulla; however, the expression of CD3 and CD5 antigens by the majority of cortical thymocytes raises the possibility that the maturation of thymocytes starts in the cortex.

Spleen. B lymphocytes identified with antibodies against IgM, $\operatorname{IgD}, \mathrm{CD} 20$, and to a lesser extent CD21, were found mainly in primary follicles of the white pulp with some cells scattered throughout the red pulp. A few $\operatorname{IgA}_{1}{ }^{+}$and $\mathrm{IgA}_{2}{ }^{+}$cells were present, located in primary follicles of one fetal spleen. Secondary follicles were not observed in fetal tissue. $\mathrm{CD}^{+}, \mathrm{CD}^{+}$, and $\mathrm{CD}^{+}$lymphocytes were predominant in the periarteriolar sheath and scattered throughout the red pulp. The endothelial cells of the splenic sinusoids were $\mathrm{CD}^{-}$, in contrast to the marked staining reported in adult spleens (15). Extensive staining occurred in the red pulp with anti-CD4 antibody, staining both lymphocytes and macrophages. The antibodies against $\mathrm{MHC}$ class II antigens predominantly stained cells in the primary follicles. Some dendritic staining was also present in the red pulp.

Liver. Cells bearing $\operatorname{IgM}$ and $\operatorname{IgD}$ were the most frequent $\mathrm{B}$ cells found sparsely scattered throughout the parenchyma of fetal liver. $\mathrm{CD} 20^{+}$cells were found rarely in only two fetal livers. Staining for $C D 21, \operatorname{Ig} A_{1}, \operatorname{Ig} A_{2}$, and $\operatorname{IgG}$ was not demonstrable in all samples examined. Many $\mathrm{CD}^{+}$cells with dendritic staining were evenly distributed in the sinusoids; however, $\mathrm{CD}^{+}$and $\mathrm{CD} 8^{+}$cells were sparse. Therefore, most of the $\mathrm{CD}^{+}$cells were not $\mathrm{T}$ cells but were probably macrophages (Kupffer cells). Most HLA-DR ${ }^{+}$cells in the sinusoids demonstrated dendritic staining and many cells in the portal tracts had peripheral staining with anti-HLA-DR. Expression of MHC class II antigens was not detected on intrahepatic bile ducts.
Small intestine. The lymphoid cells in the fetal intestinal mucosa were distributed as scattered cells or in small aggregates (primary follicles). Sparsely scattered lymphocytes stained with antibody against $\mathrm{CD} 20, \operatorname{IgM}, \operatorname{IgD}$, and occasionally CD21 and were considered to be $\mathrm{B}$ lymphocytes. $\mathrm{No} \operatorname{IgA}_{1}{ }^{+}, \mathrm{IgA}_{2}{ }^{+}$, or $\mathrm{IgG}^{+}$ cells were present in the lamina propria of fetal intestine or the proximal jejunum of the 1-d-old infant; however, as expected, $\mathrm{IgA}_{1}{ }^{+}$and $\mathrm{IgA}_{2}{ }^{+}$cells represented the predominant $\mathrm{B}$ cell population in the lamina propria of postnatal small intestine (Fig. $1 b)$. Lymphocyte staining for IgM, IgD, CD20, and occasionally CD21 was present in the small intestinal lamina propria of postnatal specimens. In order of predominance, $\mathrm{CD}^{+}, \mathrm{CD}^{+}$, and $\mathrm{CD}^{+}$cells were readily identified in the lamina propria of all fetal intestine as well as all specimens obtained postnatally. Many of the $\mathrm{CD}^{+}$cells had the morphologic appearance of macrophages or dendritic cells.

Most B cells in fetal intestinal tissue were clustered in lymphoid aggregates, characteristic of primary follicles staining with antibodies against IgM, IgD, CD20, and faintly CD21. Many primary follicles were present in fetal cecum and appendix. In two specimens some $\mathrm{IgA}_{1}{ }^{+}, \mathrm{IgA}_{2}{ }^{+}$, and $\mathrm{IgG}^{+}$cells were prominently stained in lymphoid aggregates (Fig. 1a).

Both primary and secondary lymphoid follicles were found in the postnatal specimens except for the 1-d-old infant. Germinal centers stained for IgM, IgG, and CD20; whereas, the mantle zones demonstrated the staining characteristics of a primary follicle. Interfollicular cells stained with antibodies against CD4, $\mathrm{CD} 3$, and $\mathrm{CD} 8$ with $\mathrm{CD}^{+}$cells predominating.

Occasional intraepithelial lymphocytes $(0-1$ cells per highpowered field) stained with CD3 and CD8 antibodies were present in all six fetuses and the 1-d-old infant (Fig. 2a). CD4 ${ }^{+}$ intraepithelial lymphocytes were absent in four fetuses and the 1-d-old infant and were observed only rarely in two fetuses. Similarly, intraepithelial lymphocytes that were slightly more numerous (one to two cells per high-powered field) in the intestine of older infants and children were predominately $\mathrm{CD}^{+}$and $\mathrm{CD}^{+}$(Fig. $2 b$ ).

Many HLA-DR ${ }^{+}, \mathrm{HLA}-\mathrm{DQ}^{+}$, and $\mathrm{HLA}-\mathrm{DP}^{+}$cells were present in the lamina propria of all pre- and postnatal small intestine sections stained, with prominent dendritic staining observed with HLA-DR and HLA-DQ antibodies. No MHC class II antigen expression was observed on the epithelial cells of any fetal intestinal tissue or the newborn intestine (Fig. $3 a$ ). The epithelium of the proximal jejunum of the three older children (14 mo to $3 \mathrm{y}, 10 \mathrm{mo}$ ) was HLA-DR ${ }^{+}$(Fig. $3 b$ ) and in two of the three it was also HLA-DQ ${ }^{+}$. Epithelium of the distal ileum did not stain with anti-HLA-DR in two children ( 8 and $14 \mathrm{mo}$ ) and was HLA-DR $^{+}$in only one child (age $16 \mathrm{mo}$ ) who had a bowel resection for intussusception. Although the mucosa appeared normal in this child, the stained sections were from areas with prominent lymphoid hyperplasia. The possibility remains that lymphoid hyperplasia was associated with the intussusception and this condition resulted in a change in the epithelial cells with respect to class II antigen expression. No staining was observed with the HLA-DP antibody on fetal or postnatal intestinal epithelial cells.

The expression of MHC class I antigens was examined in three fetal and three postnatal intestinal specimens using a MAb reactive with HLA-A,B,C and was found to be present on the

Fig. 1. $\operatorname{IgA}^{+}$cells present in fetal intestine $(a)$ and postnatal intestine $(b)$. A small cluster of IgA ${ }^{+}$cells (arrows) are identified by red peripheral cellular staining in a lymphoid aggregate in the human fetal jejunum $(a)$. Several $\operatorname{IgA}^{+}$cells are present in the lamina propria of postnatal intestine (b) (magnification $160 \times$ ). Horizontal bars represent $50 \mu$.

Fig. 2. Intraepithelial lymphocytes in fetal $(a)$ and postnatal $(b)$ intestine. An occasional $\mathrm{CD}^{+}$lymphocyte is present (arrows) in the epithelium $(E)$ of the proximal jejunum of human fetus, and 6-mo-old infant $(b)$. Many $\mathrm{CD}^{+}$cells are present in the lamina propria $(L P)$ of both fetal and postnatal intestine (magnification $250 \times$ ). Horizontal bars represent $50 \mu$.

Fig. 3. THe expression of MHC class II antigen in proximal fetal jejunum (a), and 6-mo-old infant (b), determined by immunohistochemical staining with anti-HLA-DR antibody. Many stained cells are present in the lamina propria of both specimens. Some large cells demonstrate dendritic staining (small arrow). Epithelial cell staining is not observed in the fetal intestine, but is present on the intestinal epithelium of the 6-mo-old infant (large arrow) (magnification 160X). Horizontal bars represent $50 \mu$. 
Table 2. Characteristics of human fetal and postnatal small intestine

\begin{tabular}{|c|c|c|}
\hline & Fetus & Postnatal \\
\hline Lymphoid follicles & $\begin{array}{l}\text { Primary follicles containing } \operatorname{IgM}^{+} \text {and } \\
\operatorname{IgD}^{+} \text {cells (IgA } \\
\text { some fetuses) }\end{array}$ & Primary and secondary follicles \\
\hline \multicolumn{3}{|l|}{ Lamina propria } \\
\hline T Cells & $\begin{array}{l}\text { Many } \mathrm{CD}^{+}, \mathrm{CD}^{+}, \text {and } \mathrm{CD} 8^{+} \text {cells } \\
\text { with } \mathrm{CD} 4^{+} \text {cells predominating }\end{array}$ & Distribution similar to that in fetuses \\
\hline B Cells & $\begin{array}{l}\text { Sparsely scattered } \mathrm{IgM}^{+} \text {and } \mathrm{IgD}^{+} \\
\text {cells. No } \mathrm{IgG}^{+} \text {or } \mathrm{IgA}^{+} \text {cells }\end{array}$ & $\begin{array}{l}\text { Predominantly IgA }{ }^{+} \text {cells. Some } \\
\operatorname{lgD}^{+} \text {and } \operatorname{IgM}^{+} \text {cells }\end{array}$ \\
\hline Epithelium & $\begin{array}{l}\text { Rare }\left(0-1 \text { cells } / \mathrm{HPF}^{*}\right) \text { intraepithelial } \\
\text { lymphocytes; predominantly } \\
\mathrm{CD}^{+}, \mathrm{CD} 8^{+} . \text {Enterocytes MHC } \\
\text { class } \mathrm{I}^{+} \text {, class } \mathrm{II}^{-}\end{array}$ & $\begin{array}{l}\text { Rare-occasional }(1-2 \text { cells/HPF) in- } \\
\text { traepithelial lymphocytes, pre- } \\
\text { dominantly } \mathrm{CD}^{+}, \mathrm{CD} 8^{+} \text {. Entero- } \\
\text { cytes } \mathrm{MHC} \text { class } \mathrm{I}^{+} \text {and variably } \\
\text { class } \mathrm{II}^{+}\end{array}$ \\
\hline
\end{tabular}

\footnotetext{
* High powered field.
}

intestinal epithelial cells prenatally as well as postnatally. Epithelial cell staining was not observed with anti-CD4 in any of the intestinal tissues examined. A comparison of the salient immunohistochemical features of fetal and postnatal small intestine is shown in Table 2.

Colon. $\mathrm{CD} 20^{+}$cells were present mainly in lymphoid aggregates in the colon of all six fetuses. Lightly stained CD $21^{+}$cells were present in small lymphoid aggregates of three fetal colons. $\mathrm{IgM}^{+}$and $\mathrm{IgD}^{+}$cells were sparsely distributed in the lamina propria of five specimens and were absent completely in one. Neither $\mathrm{IgA}_{1}{ }^{+}, \mathrm{IgA}_{2}{ }^{+}$, nor $\mathrm{IgG}^{+}$cells were identified in any fetal colonic tissue. Fewer $\mathrm{T}$ cells were present in the colon specimens than in the small intestine, but the lamina propria contained scattered $\mathrm{T}$ cells identified by CD3, CD4, and CD8. No CD4 intraepithelial lymphocytes were identified, and rare $\mathrm{CD}^{+}$intraepithelial lymphocytes were found in only one fetal colon. No MHC class II antigen expression was detected on the colonic epithelium but there was prominent staining of cells in the lamina propria with all three HLA antibodies.

\section{DISCUSSION}

Lymphocyte development previously has been characterized in humans and nonhuman species $(3,5,6,13,16-19)$; however, few studies have investigated the normal distribution and postnatal changes of lymphocytes in the human fetal intestinal mucosa $(7-9,20)$. Pre-B cells, which contain intracytoplasmic $\mu$ heavy chains but lack surface IgM, first appear in the liver by 8 wk gestational age (17) and then in the bone marrow around the 12 th wk of gestation $(5,18)$. By 16 wk gestational age, B cells with surface IgM and IgD are found in fetal liver, bone marrow, spleen, lymph node, and tonsil $(5,21)$.

The maturation of $\mathrm{T}$ lymphocytes progresses through an orderly process of acquisition and loss of distinct cell surface antigens during intrathymic differentiation (3). The expression of $\mathrm{T}$ cell associated antigens has been demonstrated in fetal thymus as early as $10 \mathrm{wk}$ gestational age (22) and by $12 \mathrm{wk}$, the fetal thymocyte phenotype is identical to the neonatal thymocyte phenotype $(13,19)$. The appearance of $\mathrm{T}$ cells in the thymus precedes the finding of cells bearing $T$ cell-associated antigens in the bone marrow and liver that occurs around the 13th wk of gestation (2). The distribution of $\mathrm{T}$ cells in fetal thymus, spleen, and liver in this investigation, was for the most part consistent with previous reports $(2,3,13,15,19)$. The majority of fetal thymocytes expressed the T cell antigens CD1, CD3, CD4, and CD8. In fetal liver and spleen, cells expressing CD4 were very numerous and scattered evenly throughout the parenchyma. Cells expressing CD3 and CD8 were less numerous, and, in the spleen, were predominately located in the periarteriolar sheath. In contrast, Rosenthal et al. (19), using fluorescence-activated cell sorter analysis of a splenic cell suspension, have reported a prevalence of $\mathrm{CD}^{+}$cells compared to the $\mathrm{CD} 4^{+}$cells in the spleen. The relatively larger number of $\mathrm{CD}^{+}$cells in our study may be due in part to the staining of macrophages as well as $T$ helper/inducer lymphocytes with the CD4 antibody.

Lymphoid cells have been identified in human fetal intestinal lamina propria as early as $8 \mathrm{wk}$ gestation (20) and organization of Peyer's patches occurs between 3-7 wk later $(4,7)$. However, there are only limited studies describing immunohistochemical characterization of fetal intestine. Clusters of cells expressing CD4 but not CD3, have been identified in the terminal ileum of fetuses by 11 wk gestation (7). These cells were probably macrophages. Lymphocytes bearing $\mathrm{T}$ and $\mathrm{B}$ cell-associated antigens were found between 14 and $16 \mathrm{wk}$ gestational age (7).

In our study, the distribution of lymphocytes bearing various $\mathrm{T}$ and $\mathrm{B}$ cell surface markers was characterized throughout the human fetal intestine and compared with normal postnatal intestinal tissue. Lymphoid aggregates were present in both proximal and distal segments of fetal intestine and were numerous in the cecum. These primary follicles were identified by anti-CD20 and (weakly) anti-CD21 in the same distribution as $\mathrm{IgM}^{+}$and $\mathrm{IgD}^{+}$cells. Germinal centers, or secondary lymphoid follicles, were not identified in any fetal tissue examined. Interestingly, $\mathrm{IgG}^{+}$lymphocytes were occasionally present in the spleen and thymus of one fetus, and some $\operatorname{IgA}_{1}{ }^{+}$and $\operatorname{IgA}_{2}{ }^{+}$cells were found in primary follicles of the spleen or intestine of three fetuses.

The finding of $\mathrm{IgG}^{+}$and $\mathrm{IgA}^{+}$lymphocytes in fetal tissue could be the result of antigen-independent $\mathrm{B}$ cell differentiation (21), a fetal immune response to intrauterine infection (23), or an immune response induced by antiidiotypic antibodies from the mother (24). The presence of IgG- and IgA-bearing B cells have been previously reported in human fetal tissues (21) but not in fetal intestine. Fluorochrome-labeled goat antibodies specific for Ig heavy chains were used in double-staining experiments to demonstrate the presence of IgG- and IgA-bearing lymphocytes in fetal liver as early as $11 \mathrm{wk}$ gestational age (21). Most of the $\mathrm{IgA}^{+}$and $\mathrm{IgG}^{+}$cells also expressed IgM in contrast with $\mathrm{B}$ lymphocytes from adults that expressed $\operatorname{IgG}$ and $\mathrm{IgA}$ as single isotypes (21). Evidence also exists that the fetus can secrete IgA in utero as a result of infection $(23,25)$. The presence of secretory IgA and IgM against Escherichia coli 0 and poliovirus type 1 antigens in saliva and meconium collected from newborns also supports the hypothesis that the fetus is capable of isotypic switching (24). Mellander et al. (24), suggested that because the fetuses had not been exposed to poliovirus in utero, the antibodies were induced by antiidiotypic antibodies from the mother. Although the mechanism is not known, these previous studies support our observation that fetal intestinal tissue may contain both IgG- and IgA-bearing lymphocytes.

The distribution of B lymphocyte markers was also examined in intestinal specimens of seven infants and children. The earliest postnatal specimen examined was the proximal jejunum of a 1d-old unfed infant in which rare $\mathrm{IgD}^{+}$lymphocytes were the only $\mathrm{B}$ cells found. This pattern resembled that of the fetus. Peyer's 
patches were identified in three children in which the germinal centers stained with antibodies against IgM, IgG, CD20, and occasionally $\lg \mathrm{A}_{1}$ and $\operatorname{Ig} \mathrm{A}_{2}$. The mantle zone as well as primary follicles demonstrated staining with antibodies against IgM, $\operatorname{IgD}$, CD20, and faintly with anti-CD21. This pattern of staining is characteristic of secondary follicles and has been well described in human lymph nodes and tonsil (26). Lymphocytes and plasma cells expressing $\operatorname{Ig} \mathrm{A}_{2}$ were the most prevalent $\mathrm{B}$ cells in the lamina propria of postnatal specimens with $\mathrm{IgD}^{+}$lymphocytes only found occasionally. In contrast, B cells expressing CD20, CD21, IgM or IgD were sparsely scattered in the lamina propria of fetal intestine and most were near primary follicles; however, more $\mathrm{IgM}^{+}$and $\mathrm{IgD}^{+}$cells were present in the distal ileum than in the proximal jejunum or colon. Cells bearing $\operatorname{Ig} A_{1}, \lg A_{2}$, or $\operatorname{IgG}$ were not found in the lamina propria of any fetal intestinal tissue examined. The concentration of B cells in primary follicles and their sparse distribution in the lamina propria of fetal intestine probably reflects the low amount of antigen to which the fetal intestinal mucosa is exposed. After antigenic stimulation, Igsecreting precursor cells migrate from Peyer's patches to mesenteric lymph nodes (27). They then enter the systemic blood circulation via the thoracic duct and after further division and maturation, the B cells migrate to the lamina propria where they differentiate into Ig-secreting plasma cells (28). The intestinal mucosa is exposed to a wide variety of environmental antigens postnatally and develops secondary lymphoid follicles as $\operatorname{lgA}{ }^{+}$ cells become the predominant cells of the B cell lineage in the lamina propria.

A predominance of $\mathrm{CD}^{+}$cells was found in the lymphoid aggregates and lamina propria of all intestinal tissue examined. The relatively low proportion of cells that expressed CD8 compared to the pan- $T$ cell antigen $\mathrm{CD} 3$ indicates that $T$ lymphocytes of the helper/inducer phenotype predominate in the intestinal lamina propria of fetuses as well as infants and children. Two intestinal lymphoid aggregates in fetal small intestine demonstrated distinct zonation of $\mathrm{B}$ cells surrounded by $\mathrm{T}$ cells. Few $\mathrm{T}$ cells $\left(\mathrm{CD}^{+}\right.$and $\left.\mathrm{CD}^{+}\right)$were present in the germinal centers of Peyer's patches of postnatal intestine, but were densely populated in the interfollicular regions.

Intraepithelial lymphocytes bearing CD3 and CD8 antigens were rarely or only occasionally found in fetal intestinal specimens. No $\mathrm{CD}^{+}$intraepithelial lymphocytes were identified in four fetuses and were rarely present in two. Intraepithelial lymphocytes in infants and children were also predominately $\mathrm{CD}^{+}$ and $\mathrm{CD}^{+}$but the number of these cells was only slightly increased compared with fetal intestine. The compartmentalization of $\mathrm{T}$ lymphocytes in fetal and infant intestine are consistent with previous findings in adult intestinal tissue that the majority of $T$ lymphocytes in the lamina propria expresses the $T$ helper/inducer phenotype; whereas, most intraepithelial lymphocytes express the phenotype associated with cytotoxic/suppressor $\mathrm{T}$ cells (12, 29). The paucity of intraepithelial lymphocytes in infants and children as well as fetal tissue suggests that the increase in intraepithelial lymphocytes occurs postnatally and that intraluminal antigen exposure is not the only factor involved in lymphocytes populating the intestinal epithelium.

MHC II antigens are present on a wide variety of cells including dendritic cells, macrophages, B cells, activated T cells, endothelial cells, and in some instances epithelial cells. Although MHC class I antigens are found on normal intestinal epithelial cells, increased expression of HLA-DR has been reported on the enterocytes of patients with inflammatory bowel disease (30) and celiac disease (31). No expression of MHC class II antigens was detected on the intestinal epithelium of any fetus or the 1-d-old infant, but was expressed on the epithelium of the proximal jejunum in three postnatal specimens. In contrast, MHC class I expression was identified on the intestinal epithelial cells of three fetal specimens tested. Epithelial cells adjacent to mucosal lymphoid aggregates did not express class II antigen when the surrounding epithelium was negative. These findings are in con- trast to a previous report of preferential staining of epithelial cells adjacent to lymphoid tissue in the adult human gastrointestinal tract (32). Thus, the intestinal epithelial cells of the fetus do not express these immunologically regulated epitopes, raising the hypothesis that postnatal events such as luminal antigen may play a role in their induction. Postnat.ily, the distribution of class II antigen on the surface of the infant intestine does not appear to be uniformly distributed. Although the factors that regulate immunologic maturation of the gastrointestinal tract in humans is unclear, this study has identified specific mucosal lymphocyte and epithelial cell phenotypes that change with development.

Acknowledgments. The authors thank Drs. Judah Folkman and Robert B. Hendren as well as the pathology department of the Brigham and Women's Hospital for their cooperation with this study.

\section{REFERENCES}

1. Walker WA, Isselbacher KJ 1977 Intestinal antibodies. N Engl J Med 297:767773

2. Kamps WA, Cooper MD 1984 Development of lymphocyte subpopulations identified by monoclonal antibodies. J Clin Immunol 4:36-39

3. Reinherz EL, Kung PC, Goldstein G, Levey RH, Schlossman SF 1980 Discrete stages of human intrathymic differentiation: Analysis of normal thymocytes and leukemia lymphoblasts of T-cell lineage. Proc Natl Acad Sci USA 77:1588-1592

4. Keleman E, Calvo W, Eliedner TM 1979 Atlas of Human Hematopoietic Development. Springer-Verlag, New York

5. Bofill M, Janossy G, Janossa M, Burford GD, Seymour GJ, Wernet P, Keleman E 1985 Human B cell development II. Subpopulations in the human fetus. J Immunol 134:1531-1538

6. Asma GEM, Pichler W, Schuit HRE, Knapp W, Hijmans W 1977 The development of lymphocytes with $\mathrm{T}$ - or B-membrane determinants in the human fetus. Clin Exp Immunol 29:278-285

7. Spencer J, MacDonald TT, Finn T, Isaacson PG 1986 The development of gut associated lymphoid tissue in the terminal ileum of fetal human intestine. Clin Exp Immunol 64:536-543

8. Spencer J, Dillon SB, Isaacson PG, MacDonald TT $1986 \mathrm{~T}$ cell subclasses in fetal human ileum. Clin Exp Immunol 65:553-558

9. MacDonald TT, Spencer J 1988 Evidence that activated mucosal $\mathrm{T}$ cells play a role in the pathogenesis of enteropathy in human small intestine. J Exp Med 167:1341-1349

10. Moore KL 1977 The Developing Human. WB Saunders, Philadelphia, pp 8195

11. Patten BM 1968 Human Embryology. McGraw Hill, New York, pp 142-143

12. Cerf-Bensussan N, Schneeberger EE, Bhan AK 1983 Immunohistologic and immunoelectron microscopic characterization of the mucosal lymphocytes of human small intestine by the use of monoclonal antibodies. J Immunol 130:2615-2622

13. Asma GEM, van den Bergh RL, Vossen JM 1983 Use of monoclonal antibodies in a study of the development of $\mathrm{T}$ lymphocytes in the human fetus. Clin Exp Immunol 53:429-436

14. Bhan AK, Reinherz EL, Poppema S, McCluskey RT, Schlossman SF 1980 Location of $\mathrm{T}$ cell and major histocompatibility complex antigens in the human thymus. J Exp Med 152:771-782

15. Timens W, Poppema S 1985 Lymphocyte compartments in human spleen. An immunohistologic study in normal spleens and noninvolved spleens in Hodgkin's disease. Am J Pathol 120:443-454

16. Kincade PW, Lee G, Watanabe T, Sun L, Scheid MP 1981 Antigens displayed on murine B lymphocyte precursors. J Immunol 127:2262-2268

17. Asma GEM, van den Bergh RL, Vossen JM 1984 Development of pre-B and B lymphocytes in the human fetus. Clin Exp Immunol 56:407-414

18. Kamps WA, Cooper MD 1982 Microenvironmental studies of pre-B and B cell development in human and mouse fetuses. J Immunol 129:526-531

19. Rosenthal P, Rimm IJ, Umiel T, Griffin JD, Osathanondh R, Schlossman SF, Nadler LM 1983 Ontogeny of human hematopoietic cells: analysis using monoclonal antibodies. J Immunol 31:232-237

20. Orlic D, Lev R 1977 An electron microscopic study of intraepithelial lymphocytes in human fetal small intestine. Lab Invest 37:554-561

21. Gathings WE, Lawton AR, Cooper MD 1977 Immunofluorescent studies of the development of pre-B cells, B lymphocytes and immunoglobulin isotype diversity in humans. Eur $\mathrm{J}$ Immunol 7:804-810

22. Lobach DF, Hensley LL, Ho W, Haynes BF 1985 Human T cell antigen expression during the early stages of fetal thymic maturation. J Immunol 135:1752-1759

23. Cederqvist LL, Kimball AC, Ewool LC, Litwin SD 1977 Fetal immune response following congenital toxoplasmosis. Am J Obset Gynecol 50:200204

24. Mellander L, Carlsson B, Hanson LA 1986 Secretory IgA and IgM antibodies to $\mathrm{E}$. coli $\mathrm{O}$ and poliovirus type $\mathrm{I}$ antigens occur in amniotic fluid, meconium and saliva from newborns. A neonatal immune response without antigenic 
exposure: a result of anti-idiotype induction? Clin Exp Immunol 63:555561

25. Cederqvist LL, Litwin SD 1974 Production of alpha ${ }_{1}$ and alpha $_{2}$ immunoglobulin heavy chains during fetal life. J Immunol 112:1605-1608

26. Bhan AK, Nadler LM, Stashenko P, McCluskey RT, Schlossman SF 1981 Stages of B cell differentiation in human lymphoid tissue. J Exp Med 154:737-749

27. Husband AJ, Gowans JL 1978 The origin and antigen-dependent distribution of IgA-containing cells in the intestine. J Exp Med 148:1146-1160

28. Husband AJ 1982 Kinetics of extravasation and redistribution of IgA-specific antibody containing cells in the intestine. J Immunol 123:1355-1359

29. Cerf-Bensussan N, Guy-Grand D, Griscelli C 1985 Intraepithelial lymphocytes of human gut: isolation, characterisation and study of natural killer activity. Gut 26:81-88

30. Hirata I, Austin LL, Blackwell WH, Weber JR, Dobbins WO III 1986 Immunoelectron microscopic localization of HLA-DR antigen in control small intestine and colon and in inflammatory bowel disease. Dig Dis Sci 31:13171330

31. Arnaud-Battandier F, Cerf-Bensussan N, Amsellem R, Schmitz J 1986 Increased HLA-DR expression by enterocytes in children with celiac disease. Gastroenterology 91:1206-1212

32. Spencer J, Finn T, Isaacson PG 1986 Expression of HLA-DR antigens on epithelium associated with lymphoid tissue in the human gastrointestinal tract. Gut 27:153-157 